\title{
Effect of Water Stress Induced by Polyethylene Glycol 6000 on Somatic Embryogenesis in Cocoa (Theobroma cacao L.)
}

\author{
Manlé Tokpapon Eliane ${ }^{1,2 *}$, Kouassi Kan Modeste ${ }^{3}$, Soumahoro Brahima André4, \\ Koffi Kouablan Edmond1, Koné Mongomaké2
}

\footnotetext{
${ }^{1}$ Laboratoire Central de Biotechnologie (LCB), Centre National de Recherche Agronomique (CNRA), Abidjan, Côte d'Ivoire ${ }^{2}$ Laboratoire de Biologie et Amélioration des Productions Végétales, UFR Sciences de la Nature, Université Nangui Abrogoua, Abidjan, Côte d'Ivoire

${ }^{3}$ Laboratoire de Physiologie Végétale, Université Félix Houphouët-Boigny, Abidjan, Côte d’Ivoire

${ }^{4}$ Section SVT, Département des Sciences et Technologies, Ecole Normale Supérieure d'Abidjan, Abidjan, Côte d'Ivoire

Email: *elianemanle@gmail.com
}

How to cite this paper: Eliane, M.T., Modeste, K.K., André, S.B., Edmond, K.K. and Mongomaké, K. (2019) Effect of Water Stress Induced by Polyethylene Glycol 6000 on Somatic Embryogenesis in Cocoa (Theobroma cacao L.). Agricultural Sciences, 10, 1240-1254.

https://doi.org/10.4236/as.2019.109092

Received: July 23, 2019

Accepted: September 26, 2019

Published: September 29, 2019

Copyright $\odot 2019$ by author(s) and Scientific Research Publishing Inc. This work is licensed under the Creative Commons Attribution International License (CC BY 4.0).

http://creativecommons.org/licenses/by/4.0/

\begin{abstract}
Climate change, coupled with insufficient and irregular rains, led to a decline in the productivity of Ivorian cocoa production. The present study aimed to screen three cocoa (Theobroma cacao L.) genotypes in order to evaluate their response to water stress at callus and somatic embryos induction and proliferation stages. Staminode and petal explants of the genotypes C1, C14 and C16 from the collection of National Center of Agronomic Research (CNRA) of Ivory Coast, were placed on medium DKW (Driver \& Kuniyuki Walnut) in the presence of different concentrations of Polyethylene glycol (PEG) $6000(0$, $25,50,75,100$ and $125 \mathrm{~g} / \mathrm{l})$. This polymer was used as osmoticum to stimulate water stress. Data were recorded for callus induction frequency, callus fresh weight, embryogenic callus percentage and average number of somatic embryos. The results obtained showed that intensity of callus proliferation decreased with increasing concentration of PEG 6000. In all genotypes tested, only the petal explants underwent somatic embryogenesis. The induction rates and average number of somatic embryos per explant were reduced with the increase in the concentration of PEG 6000. Among the tested genotypes, C1 produced somatic embryos with all concentrations of PEG 6000 and expressed highest frequencies of induction (62\%) and average number of somatic embryos per explant (6.22). This genotype would be the most tolerant to water stress. Somatic embryos obtained with high concentrations of PEG 6000 in this study provide an important basis for the selection and further production of water stress-tolerant varieties of cocoa.
\end{abstract}




\section{Keywords}

Water Stress, Cocoa, PEG 6000, Somatic Embryogenesis, Selection

\section{Introduction}

Cocoa (Theobroma cacao L.) is a crucial crop for the confectionary business, as it provides the key raw material for chocolate-based products [1]. It is a cash crop not only for producing countries but also a potential source of income for farmers. World Cocoa production is ensured to $73 \%$ by Africa. Ivory Coast is the largest world producer and accounts for $41 \%$ of global supply [2].

The crop requires a temperature between $24^{\circ} \mathrm{C}$ and $28^{\circ} \mathrm{C}$ and high humidity. Annual rainfall should be between 1250 and $3000 \mathrm{~m}^{3}$ with uniform rainfall distribution and a dry season not exceeding three months [3]. However, in recent decades, the cocoa sector in Ivory Coast suffered enormous production losses due to climate change, which is characterized by irregular and insufficient rains. A continuous shortfall in precipitation (meteorological drought) coupled with higher evapotranspiration demand leads to agricultural drought [4].

Drought is considered the single most devastating environmental stress, which decreases crop productivity more than any other environmental stress [5]. The research programs generally developed by Ivorian agricultural research institutions to improve cocoa productivity through the selection of elite varieties have rarely taken into account the effect of water stress. However, this constraint becomes more and more important as it significantly reduces the yield of plants and climate models have predicted increased severity and frequency of drought under the ongoing global climate change scenarios [6] [7].

Selection of cocoa varieties under water deficit would provide adequate planting material for farmers in areas of short rainy season. Classical methods usually used for the creation of water-deficit-tolerant varieties are limited by the long selection time and especially by the influence of several other environmental factors on the observed responses. Selection by in vitro culture with a single source of variability seems more appropriate for obtaining tolerant varieties to drought and thus mitigating the effect of climate change on the Ivorian orchard.

Plant cell and tissue culture have been a useful tool to study stress tolerance mechanisms under in vitro conditions. In vitro culture techniques minimize environmental variations due to defined nutrient media, controlled conditions and homogeneity of stress application [8]. In addition, such manipulations enable studying large plant populations and stress treatments in a limited space and short period of time [9].

Somatic embryogenesis is one of tissue culture techniques that can be used for in vitro selection. The use of somatic embryo (SE) for the in vitro selection program is very valuable because the selected traits will be inherited in the progenies 
if they are of a genetic nature [10]. Several workers have reported somatic embryogenesis in cocoa [11] [12] [13] [14]. All these studies were mainly focused on medium composition to optimize the responses of explants and genotypes to somatic embryogenesis. No reports have not yet been dedicated to in vitro selection against a biotic stress induced by drought. Therefore, this study aimed to screen cocoa genotypes $\mathrm{C} 1, \mathrm{C} 14$ and $\mathrm{C} 16$ in order to evaluate their response to water stress at callus and somatic embryos induction and proliferation levels.

Using selective agents, variability of regenerants from somatic embryogenesis (especially via callus phase) could enhance genetic variation. Polyethylene glycols (PEG) of high molecular weight have been used to simulate drought stress in plants as non-penetrable and non-toxic osmotic agents lowering the water potential in a way similar to soil drying [15] [16]. In vitro selection by culturing plant cells and tissues on medium supplemented with polyethylene glycol (PEG) has yielded drought tolerant tissues of Sweet potato [17] and Oryza sativa [18].

The study of somatic embryogenesis of cocoa under water stress is innovative, and allows the species to benefit from somaclonal variation [19] [20].

In vitro regeneration of cocoa plantlets tolerant to water deficit would promote culture of this crop throughout the country.

\section{Materials and Methods}

\subsection{Plant Materials}

The plant material consisted of staminodes and petals derived from closed flower buds of high yielding cocoa genotypes $\mathrm{C} 1, \mathrm{C} 14$ and $\mathrm{C} 16$ was obtained from the National Center of Agronomic Research of Ivory Coast. The immature closed flower buds were collected from field-grown plants at the International Center Research of Agroforestry (ICRAF) in Abidjan (Ivory Coast).

\subsection{Collection and Disinfection of Flower Buds}

Flower buds ( 4 to $5 \mathrm{~mm}$ long) were collected in the morning before 9 a.m. and transferred to the laboratory, where they were surface sterilized with $1 \%$ calcium hypochlorite $(\mathrm{m} / \mathrm{v})$ for $20 \mathrm{~min}$, followed by $70 \%$ alcohol for $1 \mathrm{~min}$, and then rinsed three times with sterile distilled water. They were then immersed in $1 \%$ $(\mathrm{m} / \mathrm{v})$ calcium hypochlorite solution containing two drops of Tween 20 for 10 min and then rinsed three times with sterile distilled water. All these steps of disinfection were achieved under a laminar flow hood.

\subsection{Preparation and Culture of Explants}

The disinfected flower buds were sliced perpendicularly to their longitudinal axis with a sterile scalpel blade. The petal and staminode explants were then isolated after dissection using sterile forceps. 15 petals and 15 staminodes explants were placed on the culture media (induction medium) per Petri dish. 


\subsection{Induction of Callus and Somatic Embryos under Water Stress Conditions}

The basal medium consisted of macro and micro elements of DKW [21] and supplemented with $2-4-5$, T ( $1 \mathrm{mg} / \mathrm{l})$ and Kinetin $(0.25 \mathrm{mg} / \mathrm{l})$, was used to induce callus and somatic embryos, asdescribed by Kouassi et al. (2017) [13]. After 28 days of culture on induction medium (IM), the induced calli were transferred onto somatic embryos development medium (ED) medium devoided of any growth regulators.

Water stress was exerted by preparing different concentrations of PEG 6000; $25,50,75,75,100$ and $125 \mathrm{~g} / \mathrm{L}$ corresponding to water potential values $(\Psi \mathrm{H})$; $-0.19,-0.5,-0.93,-1.48,-2.16 \mathrm{MPa}$, respectively following the method of Kaufman and Eckard (1971) [22]. A control set was also included and consisted of medium culture without added PEG (zero MPa).

\subsection{Culture Conditions}

The $\mathrm{pH}$ of media was adjusted to 5.7 using solutions of $0.1 \mathrm{~N} \mathrm{NaOH}$ or $\mathrm{HCl}$. Culture media were solidified with Phytagel $(2 \mathrm{~g} / \mathrm{l})$ and then autoclaved for 20 min at $121^{\circ} \mathrm{C}$ under a pressure of 1 bar. After sterilization, media aliquots of 15 $\mathrm{ml}$ were dispensed in Petri dishes.

All the Petri dishes were placed at random in a growth chamber in continuous darkness for four weeks, at average temperature of day and night of $24^{\circ} \mathrm{C} \pm 1^{\circ} \mathrm{C}$ and at $70 \%$ relative humidity. The experiment was laid out in a completely randomized design with three factors: explants, genotypes and water stress.

\subsection{Evaluation of Callogenesis and Somatic Embryogenesis}

Callogenesis was evaluated on IM after 28 days of culture. Somatic embryogenesis was evaluated on ED medium 84 days after explant culture.

The rate of callus induction (RCI), the rate of embryogenic calli (REC) and the average number of somatic embryos (ANE) per explant were estimated, respectively, as:

1) $\mathrm{RCI}=\frac{\text { Number of explants inducing calli }}{\text { Total number of explants cultured })} \times 100$

2) $\mathrm{REC}=\frac{\text { Number of callogenic explants inducing somatic embryos }}{\text { Total number of callogenic explants }} \times 100$

3) $\mathrm{ANE}=\frac{\text { Number of callogenic explants inducing somatic embryos }}{\text { Total number of embryogenic calli }} \times 100$

Fresh weight (FW) of calli was evaluated after two months of culture by weighing using an OHAUS precision balance.

\subsection{Data Analysis}

All experiments were repeated three times with four replicates pretreatment. The results were submitted to Analysis of variance (ANOVA) using the Statistica 7.1 software. The multiple rank test of Newman-Keuls at $5 \%$ threshold was used to 
separate means. For the rate assessment, an Arc sin transformation ( $\mathrm{p}=$ proportion) was realized before performing the Analysis of variance.

\section{Results}

\subsection{Effect of PEG-6000 on Callus Induction Frequency}

Table 1 shows the induction frequency of callus derived from staminode and petal explants after 28 days of culture on IM in response to various concentrations of PEG. In control (0.0\% PEG), all explants tested induced callus. Regardless of the PEG concentrations used, the callus induction frequencies from both types of explants were similar in genotype C14 (90\% to 99\%). Similarly, induction frequencies of callus derived from petal explants of genotype $\mathrm{C} 1 \mathrm{did}$ not vary significantly. When callus induction was carried out with staminode explants of genotype $\mathrm{C} 1$, the mean induction percentage reduced significantly with the increasing of level of PEG.

Table 1. Callus induction rate from staminode and petal explants of the cocoa genotypes C1, C14 and C16 on medium (IM) containing different concentrations of PEG 6000.

\begin{tabular}{|c|c|c|c|}
\hline \multirow{2}{*}{ Genotypes } & \multirow{2}{*}{$\begin{array}{c}\text { Medium } \\
\text { (Concentration of PEG } 6000(\mathrm{~g} / \mathrm{l}))\end{array}$} & \multicolumn{2}{|c|}{ Callus induction frequency (\%) } \\
\hline & & Staminodes & Petals \\
\hline \multirow{6}{*}{$\mathrm{C} 1$} & M1 (0) & $98.3 \pm 4.1^{\mathrm{a}}$ & $99.3 \pm 3.0^{\mathrm{a}}$ \\
\hline & M2 (25) & $94.4 \pm 10.5^{\mathrm{ab}}$ & $98.4 \pm 1.9^{\mathrm{a}}$ \\
\hline & M3 (50) & $89.2 \pm 15.5^{\mathrm{b}}$ & $97.2 \pm 5.8^{\mathrm{a}}$ \\
\hline & M4 (75) & $76.6 \pm 20^{\mathrm{bc}}$ & $94.7 \pm 4.4^{\mathrm{ab}}$ \\
\hline & M5 (100) & $68.8 \pm 27.4^{\mathrm{c}}$ & $93.3 \pm 5.6^{\mathrm{ab}}$ \\
\hline & M6 (125) & $66.1 \pm 31.9^{c}$ & $92.7 \pm 5.2^{\mathrm{ab}}$ \\
\hline \multirow{6}{*}{$\mathrm{C} 14$} & M1 (0) & $98.3 \pm 3.0^{\mathrm{a}}$ & $99.4 \pm 1.9^{\mathrm{a}}$ \\
\hline & M2 (25) & $96.6 \pm 4.4^{\mathrm{a}}$ & $97.2 \pm 6.0^{\mathrm{a}}$ \\
\hline & M3 (50) & $93.8 \pm 6.6^{\mathrm{ab}}$ & $97.2 \pm 3.4^{\mathrm{a}}$ \\
\hline & M4 (75) & $93.3 \pm 6.3^{\mathrm{ab}}$ & $96.6 \pm 6.6^{\mathrm{a}}$ \\
\hline & M5 (100) & $91.1 \pm 7.7^{\mathrm{ab}}$ & $96.6 \pm 6.6^{\mathrm{a}}$ \\
\hline & M6 (125) & $90.0 \pm 9.9^{\mathrm{ab}}$ & $92.2 \pm 9.7^{\mathrm{ab}}$ \\
\hline \multirow{6}{*}{$\mathrm{C} 16$} & M1 (0) & $96.1 \pm 5.2^{\mathrm{a}}$ & $98.8 \pm 2.5^{\mathrm{a}}$ \\
\hline & M2 (25) & $95.0 \pm 5.7^{\mathrm{ab}}$ & $97.7 \pm 4.3^{\mathrm{a}}$ \\
\hline & M3 (50) & $88.3 \pm 4.1^{\mathrm{b}}$ & $97.2 \pm 5.2^{\mathrm{a}}$ \\
\hline & M4 (75) & $78.8 \pm 21.8^{\mathrm{bc}}$ & $87.7 \pm 17.7^{\mathrm{b}}$ \\
\hline & M5 (100) & $52.2 \pm 33.9^{\mathrm{d}}$ & $86.1 \pm 16.4^{\mathrm{b}}$ \\
\hline & M6 (125) & $51.1 \pm 25.9^{\mathrm{d}}$ & $67.7 \pm 33.2^{\circ}$ \\
\hline
\end{tabular}

The means followed by the same letter are statistically equal (test of Newman-Keuls at 5\% threshold); means \pm standard deviation; M1 to M6: Culture media realized with different concentration of PEG. 
A reduction in callus induction frequency from both explants staminode and petal was also observed with the genotype C16. The lowest percentages of callus induction were exhibited with the highest concentrations of PEG; 75, 100 and $125 \mathrm{~g} / \mathrm{L}$.

\subsection{Effect of PEG-6000 on Callus Fresh Weight}

Induction and proliferation of callus derived from staminode and petal explants of the genotypes $\mathrm{C} 1, \mathrm{C} 14$ and $\mathrm{C} 16$ were observed on medium containing different concentrations of PEG. However with highest concentrations of PEG (125 $\mathrm{g} / \mathrm{L}$ ), tissue necrosis appeared (Figure 1).

Significant differences were observed among the genotypes, PEG concentrations and their interactions for the callus proliferation (Table 2). As the PEG 6000 concentration in the medium increased, there was a decrease in callus fresh weight derived from both explants staminode and petal with all the genotypes tested. Reduced callus growth was more important with genotype $\mathrm{C} 1$ followed by genotype $\mathrm{C} 16$.

\subsection{Effect of PEG 6000 on Embryogenic Callus Percentages and Average Number of Somatic Embryos}

Calli derived staminode and petal explants were transferred on ED medium

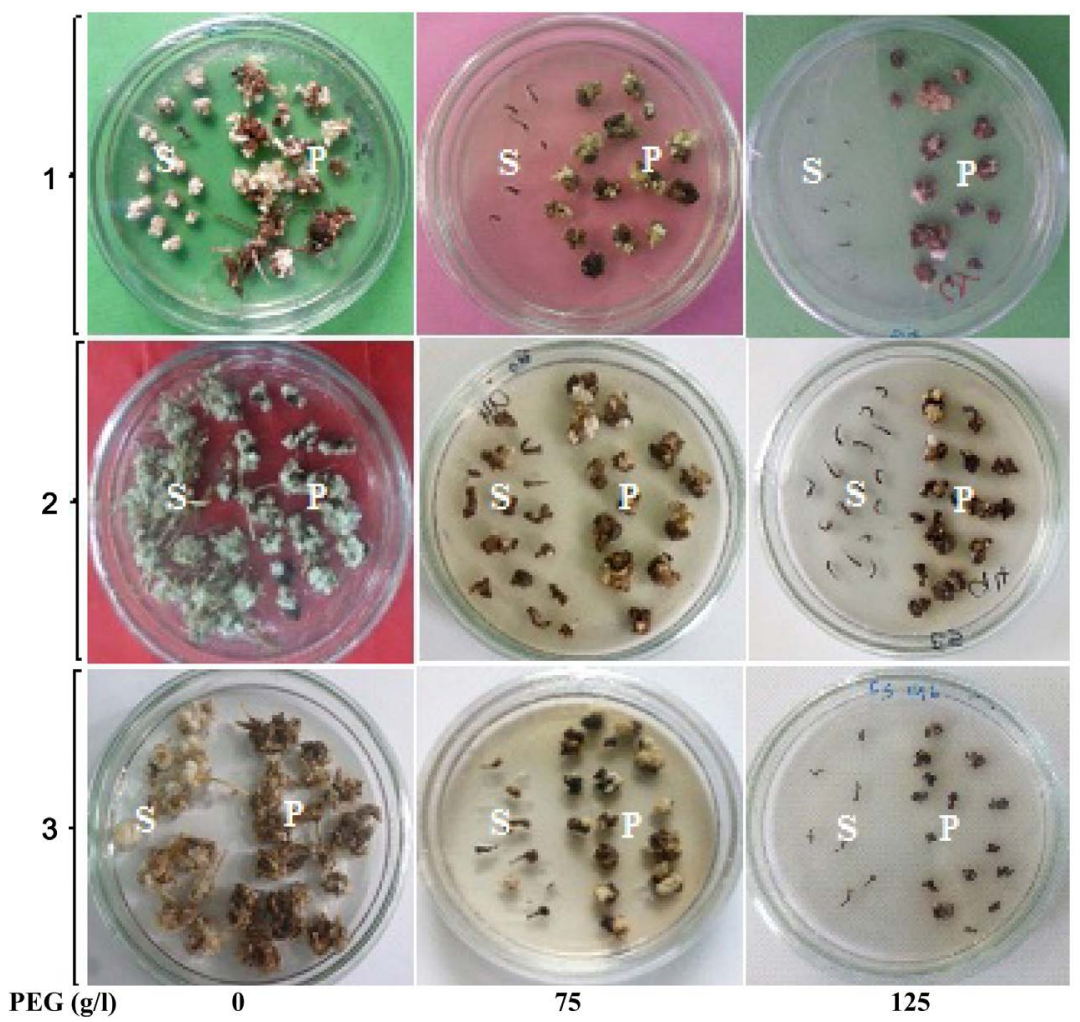

Figure 1. Three-month-old calli induced from the staminode $(\mathrm{S})$ and petal $(\mathrm{P})$ explants of genotypes C1 (1), C14 (2) and C16 (3), on medium ED containing different concentrations of PEG 6000. 
Table 2. Mean callus fresh weight of staminode and petal explants of the cacao genotypes C1, C14 and C16 after 4 weeks on ED medium containing different concentrations of PEG 6000 .

\begin{tabular}{|c|c|c|c|c|}
\hline \multirow[b]{2}{*}{ Explants } & \multicolumn{4}{|c|}{ Callus fresh weight per explant (mg) } \\
\hline & $\begin{array}{c}\text { Medium } \\
\text { (Concentration } \\
\text { of PEG } 6000 \mathrm{~g} / \mathrm{l} \text { ) }\end{array}$ & $\mathrm{C} 1$ & $\begin{array}{c}\text { Genotypes } \\
\text { C14 }\end{array}$ & $\mathrm{C} 16$ \\
\hline \multirow{6}{*}{ Petals } & M1 (0) & $66.4 \pm 4.8^{\mathrm{a}}$ & $235.8 \pm 6.6^{\mathrm{a}}$ & $147.1 \pm 5.5^{\mathrm{a}}$ \\
\hline & M2 (25) & $58.4 \pm 0.9^{\mathrm{a}}$ & $148.2 \pm 13.0^{\mathrm{bc}}$ & $81.0 \pm 0.0^{c}$ \\
\hline & M3 (50) & $38.4 \pm 3.9^{\mathrm{b}}$ & $132.9 \pm 12.5^{\mathrm{cd}}$ & $71.8 \pm 10.7^{\text {cd }}$ \\
\hline & M4 (75) & $32.9 \pm 2.0^{\mathrm{b}}$ & $120.2 \pm 12.1^{\mathrm{cd}}$ & $61.5 \pm 8.9^{\mathrm{de}}$ \\
\hline & M5 (100) & $29.3 \pm 5.3^{\mathrm{b}}$ & $109.3 \pm 11.1^{\mathrm{d}}$ & $48.2 \pm 2.1^{\mathrm{e}}$ \\
\hline & M6 (125) & $29.7 \pm 0.4^{\mathrm{b}}$ & $43.2 \pm 5.0^{\mathrm{ef}}$ & $23.4 \pm 3.6^{\mathrm{f}}$ \\
\hline \multirow{6}{*}{ Staminodes } & M1 (0) & $65.1 \pm 10.0^{\mathrm{a}}$ & $172.4 \pm 7.8^{\mathrm{b}}$ & $100.8 \pm 10.3^{\mathrm{b}}$ \\
\hline & M2 (25) & $8.4 \pm 2.2^{\mathrm{c}}$ & $101.0 \pm 4.7^{\mathrm{d}}$ & $19.0 \pm 0.0^{\mathrm{f}}$ \\
\hline & M3 (50) & $4.6 \pm 0.8^{\mathrm{c}}$ & $58.9 \pm 13.3^{\mathrm{e}}$ & $15.0 \pm 0.0^{\mathrm{f}}$ \\
\hline & M4 (75) & $4.6 \pm 0.3^{\mathrm{c}}$ & $22.5 \pm 4.1^{\mathrm{fg}}$ & $14.5 \pm 0.2^{\mathrm{f}}$ \\
\hline & M5 (100) & $1.8 \pm 0.3^{\mathrm{c}}$ & $20.2 \pm 2.3^{\mathrm{fg}}$ & $13.9 \pm 0.1^{\mathrm{f}}$ \\
\hline & M6 (125) & $1.5 \pm 0.2^{\mathrm{c}}$ & $3.7 \pm 0.2^{\mathrm{g}}$ & $1.7 \pm 0.2^{\mathrm{g}}$ \\
\hline $\mathrm{p}$ & & 0.0000 & 0.0232 & 0.0040 \\
\hline
\end{tabular}

In the same column, the means followed by the same letter are statistically equal (test of Newman-Keuls at 5\% threshold); mean \pm standard deviation; M1 to M6: Culture media realized with different concentration of PEG.

for the development of somatic embryos. In this study, formation of somatic embryos at different developmental stages was only observed on callus derived from the petal explant (Figure 2).

After 84 days of culture, the percentages of embryogenic callus and the number of embryos produced were recorded. The experimental results are shown in Table 3.

In this work, only petal explants induced somatic embryos. Highest percentage of embryogenic callus and average number of somatic embryos were obtained with all cocoa genotypes in control medium (0 g/L PEG 6000). Embryogenic callus percentage and average number of somatic embryos per explants decreased with increasing concentrations of PEG in all genotypes particularly at the highest PEG level. Maximum values (61.1\%; 6.2) were produced in genotype $\mathrm{C} 1$ more than in other genotypes on stressed and nonstressed media. At the highest concentrations of PEG (100 and $125 \mathrm{~g} / \mathrm{L}$ ), no induction of embryogenic callus was observed with the genotype C16. Likewise, no SE was observed with genotype C14 for PEG at $125 \mathrm{~g} / \mathrm{l}$. 


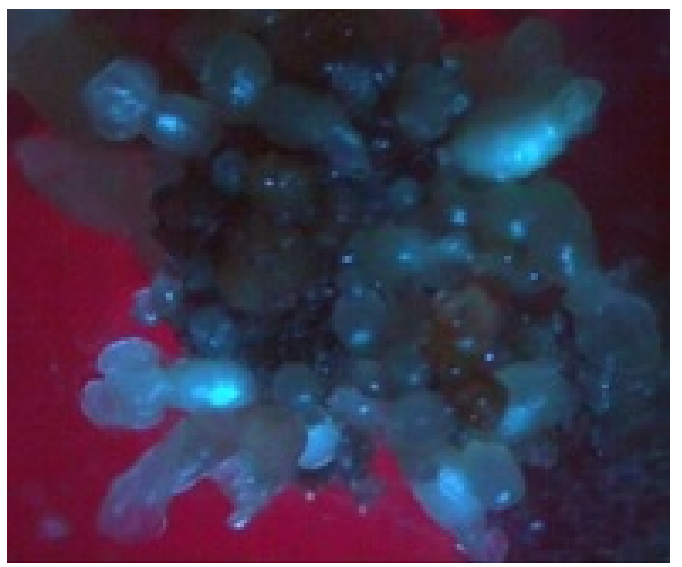

Figure 2. Developmental stages of somatic embryos on callus induced by petal explant of cocoa on culture medium ED containing different concentrations of PEG 6000.

Table 3. Induction frequency of embryogenic callus and average number of somatic embryos per explants on ED medium containing different concentrations of PEG 6000 in cacao genotypes $\mathrm{C} 1, \mathrm{C} 14$ and $\mathrm{C} 16$.

\begin{tabular}{|c|c|c|c|}
\hline \multirow[b]{2}{*}{ Genotypes } & \multirow[b]{2}{*}{$\begin{array}{l}\text { Medium (Concentration } \\
\quad \text { of PEG } 6000 \mathrm{~g} / \mathrm{l} \text { ) }\end{array}$} & \multicolumn{2}{|c|}{$\begin{array}{l}\text { Induction of somatic embryos from } \\
\text { petal explants }\end{array}$} \\
\hline & & $\begin{array}{l}\text { Induction frequency (\%) } \\
\text { of embryogenic callus }\end{array}$ & $\begin{array}{c}\text { Average number of } \\
\text { somatic embryos } \\
\text { per explants }\end{array}$ \\
\hline \multirow{6}{*}{$\mathrm{C} 1$} & M1 (0) & $61.1 \pm 8.1^{\mathrm{a}}$ & $6.2 \pm 2.6^{\mathrm{a}}$ \\
\hline & M2 (25) & $35.9 \pm 6.7^{\mathrm{b}}$ & $3.6 \pm 1.5^{\mathrm{ab}}$ \\
\hline & M3 (50) & $30.1 \pm 6.7^{\mathrm{b}}$ & $2.7 \pm 2.4^{\mathrm{b}}$ \\
\hline & M4 (75) & $25.5 \pm 6.4^{\mathrm{bc}}$ & $2.0 \pm 0.7^{b c}$ \\
\hline & M5 (100) & $4.6 \pm 2.5^{\mathrm{cd}}$ & $0.3 \pm 0.8^{\mathrm{cd}}$ \\
\hline & M6 (125) & $1.1 \pm 1.1^{\mathrm{cd}}$ & $0.1 \pm 0.2^{\mathrm{cd}}$ \\
\hline \multirow{6}{*}{$\mathrm{C} 14$} & M1 (0) & $24.8 \pm 6.1^{\mathrm{bc}}$ & $2.8 \pm 1.7^{\mathrm{b}}$ \\
\hline & M2 (25) & $21.3 \pm 5.6^{\mathrm{bc}}$ & $2.3 \pm 1.5^{\mathrm{b}}$ \\
\hline & M3 (50) & $16.1 \pm 6.7^{c}$ & $1.6 \pm 1.2^{\mathrm{bc}}$ \\
\hline & M4 (75) & $14.4 \pm 3.9^{c}$ & $1.1 \pm 1.2^{\mathrm{cd}}$ \\
\hline & M5 (100) & $5.0 \pm 2.1^{\mathrm{cd}}$ & $0.5 \pm 0.8^{\mathrm{cd}}$ \\
\hline & M6 (125) & $0.0 \pm 0.0^{\mathrm{d}}$ & $0.0 \pm 0.0^{\mathrm{d}}$ \\
\hline \multirow{6}{*}{$\mathrm{C} 16$} & M1 (0) & $22.2 \pm 4.6^{\mathrm{bc}}$ & $1.7 \pm 0.8^{\mathrm{bc}}$ \\
\hline & M2 (25) & $10.8 \pm 2.4^{c}$ & $1.5 \pm 1.0^{\mathrm{bc}}$ \\
\hline & M3 (50) & $10.2 \pm 4.9^{c}$ & $1.4 \pm 0.9^{c}$ \\
\hline & M4 (75) & $9.8 \pm 2.8^{c}$ & $0.8 \pm 1.0^{\mathrm{cd}}$ \\
\hline & M5 (100) & $0.0 \pm 0.0^{\mathrm{d}}$ & $0.0 \pm 0.0^{\mathrm{d}}$ \\
\hline & M6 (125) & $0.0 \pm 0.0^{\mathrm{d}}$ & $0.0 \pm 0.0^{\mathrm{d}}$ \\
\hline
\end{tabular}

In the same column, the averages followed by the same letter are statistically equal (test of Newman-Keuls at $5 \%$ threshold); Average \pm standard deviation; M1 to M6: Culture media realized with different concentration of PEG. 


\section{Discussion}

\subsection{Callus Induction Frequency}

The results obtained in this experiment indicated that the frequency of callus induction significantly varied with the genotypes; the type of explant and the concentration of PEG. Addition of PEG into the culture medium did not affected the callus induction frequency in genotypes C1 (petal explant) and C14 (petal and staminode explants) compared to the control $(0.0 \mathrm{~g} / \mathrm{L})$. In these conditions, the endogenous level of plant hormones would have been sufficient to initiate the response to the callogenesis. Then, the uptake of growth regulators in the culture medium to allow signals perception on the parenchymal cell membrane was not necessary. On the other hand, a significant reduction in the frequency of callus induction was noted with the staminode explant in genotype $\mathrm{C} 1$ and the staminode and petal explants with the genotype C16 when the PEG 6000 concentration was increased in the culture medium. Generally, the mean callus induction frequency decreased drastically in genotypes under higher PEG treatments than lower PEG treatments. Decrease in callus induction frequency is a typical response of plant explants when subjected to PEG stress [23] [24] [25]. Among both genotypes $\mathrm{C} 1$ and $\mathrm{C} 16$, callus induction percentages were varied distinctly suggesting that the response of callus induction for PEG treatment was genotype dependent. The difference in decreasing trend in callus induction frequency of the genotypes might further explain difference in osmotic regulation among genotypes, which enables them to maintain osmotic balance to assist initiation of callus cells under severe stress conditions or might be due to either water shortage which led to profuse mutation in cellular metabolism including protein functioning and alteration in amount of proteins [26] or altered gene expression controlling this trait [27].

\subsection{Callus Fresh Weight}

The major effect of PEG stress in callus growth is mainly observed in the form of decreasing the callus fresh weight which is a typical response in callus tissue of many crop plants [9] [18]. Such a decrease in callus fresh weight in response to PEG stress might be due to water shortage which affects development and growth of cells. Addition of PEG 6000 in solid media lowers water potential of the medium that adversely affect cell division leading to reduced callus growth [9] [28]. Cell division and cell growth are the two primary processes involved in increase of fresh weight. In general, cell division is considered to be less sensitive to drought when compared with cell enlargement or growth [9]. However, both cell expansion and cell division can be influenced by relatively mild osmotic stress. In this study callus grown with the increased PEG concentrations reduce the relative growth rate in all cocoa genotypes as in the study of Govindaraj et al. (2010) [29], Khodarahmpour (2011) [16] and Berhan et al. (2016) [30]. Significant differences were observed among the cocoa genotypes for the callus proli- 
feration. Significant differences were also found among the genotypes regarding above traits by Rao and Jabeen (2013) [31]. Similar results were also found by Hassan et al. (2004) [32] and Sakthivelu et al. (2008) [9]. These genotypic variation might be due to the induction or repression of many genes by water stress, involving a precise regulation of extensive stress-gene networks [33] [34] [35]. Products of those genes might function in stress response and tolerance at the cellular level.

\subsection{Embryogenic Callus Induction}

Establishment and propagation of embryogenic callus cultures is an essential prerequisite in cocoa tissue cultures. In the present investigation, embryogenic callus frequency decreased with increasing concentrations of PEG in all genotypes particularly at the highest PEG level. It is pertinent to note that the maximum value was produced in $\mathrm{C} 1$, more than in other genotypes on stressed and nonstressed media. Therefore the genotype $\mathrm{C} 1$ may be employed on a large scale for developing embryogenic calli and simultaneously to develop drought-tolerant lines through in vitro screening. Water potential in culture medium is a very important parameter for the induction of somatic embryos in several plant species [36].

Inhibition of somatic embryogenesis in genotypes C14 and C16 and the low rate in $\mathrm{C} 1$ with high concentrations of PEG 6000 may be due to accumulation of phenolic compounds by the explants. Somatic embryogenesis induced by Alemanno et al. (2003) [37] from cocoa flowers showed that the explants release a large amount of phenolic compounds onto the culture medium. Oxidation of these compounds derived from secondary metabolism leads to the production of toxic substances. The accumulation of these substances in the culture medium greatly reduced the embryogenic potentialities and caused cell necrosis in explants in various species [38] [39]. The embryogenic capacity expressed by explants on culture medium appears to be associated with a low concentration and a balanced distribution of polyphenols [40]. In addition, Kouassi et al. (2017) [14] showed that a high accumulation of phenolic compounds reduced the production of somatic embryos in cocoa.

However, petal explants of genotype $\mathrm{C} 1$ induced embryogenic calli in the presence of all concentrations of PEG 6000. These results showed that tissues of petal explants of this genotype have a particular potential to adapt to water stress. This indicates that tolerance to water stress is probably dependent on genotype. Work carried out by Lutts et al. (2004) [41] showed that the response to water stress induced by PEG would be dependent on genotype. In vitro culture of plant cells can foster their ability to tolerate stress at different stages of development [42]. These tissues had to develop mechanisms of water stress tolerance during the various stages of culture. In addition, the ability to adapt to water stress would involve changes in cellular metabolism characterized by the accumulation of solutes and specific proteins that can be induced rapidly under the 
influence of stress [43] [44]. Thus, in vitro culture represents a degradation of normal cellular controls leading to a cascade of genetic and epigenetic instabilities leading to the development of new genotypes [45]. Synthesis of specific proteins is one of the strategies developed by plant to survive and adapt to the conditions of water deficit [46] [47] [48]. In addition, the use of PEG as a selective agent in vitro may be responsible for genetic variation [49]. Responses observed in petals of genotype $\mathrm{C} 1$ may be associated with somaclonal variation.

\section{Conclusion}

This study showed that responses to drought in terms of the induction rates of callus, fresh weight of callus and somatic embryos vary according to the type of explant and the genotype. In callus culture, staminode and petal explants of genotypes $\mathrm{C} 14$ and $\mathrm{C} 16$ on one hand, and the petal explant of the genotype $\mathrm{C} 1$ on the other hand, were not affected by the water deficit. Fresh weight of callus decreased with increasing concentration of PEG 6000. Induction of somatic embryogenesis was only observed with the petal explants of genotype $\mathrm{C} 1$ with all the tested concentrations of PEG 6000. This genotype would thus express potential for tolerance to water deficit. So it could be used under in vitro culture conditions to select or produce drought-tolerant varieties.

\section{Acknowledgements}

The authors would like to thank Mangara Touré Mah for his technical assistance. The funds for this work were graciously donated by International Center Research of Agroforestry (ICRAF) and National Centre of Agronomic Research (CNRA) of Ivory Coast.

\section{Conflicts of Interest}

All authors agree with the content of the manuscript. They declare no conflicts of interest regarding the publication of this paper.

\section{References}

[1] Guillou, C., Fillodeau, A., Brulard, E., Breton, D., Maraschin, S., De Faria, V.D. and Simon Mand Ducos, J.P. (2018) Indirect Somatic Embryogenesis of Theobroma cacao L. in Liquid Medium and Improvement of Embryo-to-Plantlet Conversion Rate. In Vitro Cellular \& Developmental Biology_Plant, 54, 377-391. https://doi.org/10.1007/s11627-018-9909-y

[2] ICCO (2015) Production of Cocoa Beans. Quarterly Bulletin of Cocoa Statistics, 7, 1.

[3] Wood, G.A.R. and Lass, R.A. (1985) Cacao. 4th Edition, Longman, London, 620-632.

[4] Mishra, V. and Cherkauer, K.A. (2010) Retrospective Droughts in the Crop Growing Season: Implications to Corn and Soybean Yield in the Midwestern United States. Agricultural and Forest Meteorology, 150, 1030-1045. https://doi.org/10.1016/j.agrformet.2010.04.002 
[5] Lambers, H., Chapin, F.S. and Pons, T.L. (2008) Plant Physiological Ecology. 2nd Edition, Springer, New York. https://doi.org/10.1007/978-0-387-78341-3

[6] IPCC (2007) Climate Change 2007: The Physical Science Basis. Vol. 1009, Cambridge University Press, Cambridge.

[7] Walter, J., Nagy, L., Hein, R., Rascher, U., Beierkuhnlein, C., Willner, E. and Jentsch, A. (2011) Do Plants Remember Drought? Hints towards a Drought-Memory in Grasses. Environmental and Experimental Botany, 71, 34-40. https://doi.org/10.1016/j.envexpbot.2010.10.020

[8] Saepudin, A., Khumaida, N., Sopandie, D. and Ardie, S.W. (2017) In Vitro Selection of Four Soybean Genotypes Using PEG for Drought Tolerance. Jurnal Agronomi Indonesia, 45, 14-22. https://doi.org/10.24831/jai.v45i1.13749

[9] Sakthivelu, G., Akitha Devi, M.K., Giridhar, P., Rajasekaran, T., Ravishankar, G.A., Nedev, T. and Kosturkova, G. (2008) Drought-Induced Alterations in Growth, Osmotic Potential and in Vitro Regeneration of Soybean Cultivars. General Applied and Plant Physiology, 34, 103-112.

[10] Larkin, P.J. and Scowcroft, W.R. (1981) Somaclonal Variation-A Novel Source of Variability from Cell Cultures for Plant Improvement. Theoretical Applied Genetics, 60, 197-214. https://doi.org/10.1007/BF02342540

[11] Maximova, S.N., Young, A., Pishak, S. and Guiltinan, M.J. (2008) Field Performance of Theobroma cacao L. Plants Propagated via Somatic Embryogenesis. In Vitro Cellular Development Biology_ Plant, 44, 487-493. https://doi.org/10.1007/s11627-008-9130-5

[12] Boutchouang, R.P., Akitio, O.F.Z., Tchouatcheu, A.G.N. and Niemenak, N. (2016) Influence of the Position of Flowers Buds on the Tree on Somatic Embryogenesis of Cocoa (Theobroma cacao L.). International Journal of Plant Physiology and Biochemistry, 8, 7-16. https://doi.org/10.5897/IJGMB2016.0247

[13] Kouassi, M.K., Kahia, J., Kouame, N.C. and Mathias Tahi, G. (2017) Comparing the Effect of Plant Growth Regulators on Callus and Somatic Embryogenesis Induction in Four Elite Theobroma cacao L. Genotypes. Hortscience, 52, 142-145. https://doi.org/10.21273/HORTSCI11092-16

[14] Kouassi, K.M., Manlé, T.E., Koné, D., Soumahoro, A.B., Koné, T., Koffi, E.K. and Koné, M. (2017) Effect of Antioxidants on the Callus Induction and the Development of Somatic Embryogenesis of Cocoa [Theobroma cacao (L.)]. Australian Journal of Crop Science, 11, 25-30.

[15] Muhammad, H., Khan, S.A., Shinwari, Z.K., Khan, A.L., Ahmad, N. and In-Jung, L. (2010) Effect of Polyethylene Glycol Induced Drought Stress on Physio-Hormonal Attributes of Soybean. Pakistan Journal of Botany, 42, 977-986.

[16] Khodarampour, Z. (2011) Effect of Drought Stress Induced by Polyethylene Glycol (PEG) on Germination Indices in Corn (Zea mays L.) Hybrids. African Journal of Biotechnology, 10, 18222-18227. https://doi.org/10.5897/AJB11.2639

[17] Sunaryo, W., Darnaningsih, D. and Nurhasanah, N. (2019) Selection and Regeneration of Purple Sweet Potato Calli against Drought Stress Simulated by Polyethylene Glycol. F1000 Research, 8, 10. https://doi.org/10.12688/f1000research.16993.1

[18] Wani, S.H., Sofi, P.A., Gosal, S.S. and Singh, N.B. (2010) In Vitro Screening of Rice (Oryza sativa L.) Callus for Drought Tolerance. Communications in Biometry and Crop Science, 5, 108-115.

[19] Skirvin, R.M. (1978) Natural and Induced Variations in Tissue Culture. Euphytica, 
27, 241-266. https://doi.org/10.1007/BF00039141

[20] Scowcroft, W.R. and Larkin, P.J. (1982) Somaclonal Variation: A New Option for Plant Improvement. In: Vasil, K., Scowcroft, W.R. and Mey, K., Eds., Plant Improvement and Somatic Cell, Academic, New York, 159-178. https://doi.org/10.1016/B978-0-12-714980-6.50013-9

[21] Driver, J.A. and Kuniyuki, A.H. (1984) In Vitro Propagation of Paradox Walnut Root Stock. HortScience, 19, 507-509.

[22] Kaufman, M.R. and Eckard, A.N. (1971) Evaluation of Water Stress Control with PEG by Analysis of Guttation. Plant Physiology, 47, 453-458. https://doi.org/10.1104/pp.47.4.453

[23] Biswas, J., Chowdhury, B., Bhattacharya, A. and Mandal, A.B. (2002) In Vitro Screening for Increased Drought Tolerance in Rice. In Vitro Cellular and Developmental Biology, 38, 525-530. https://doi.org/10.1079/IVP2002342

[24] Abdel-Ghany, H.M., Nawar, A.A., Ibrahim, M.E., El-Shamarka, A., Selim, M.M. and Fahmi, A.I. (2004) Using Tissue Culture to Select for Drought Tolerance in Bread Wheat. Proceedings of the 4th International Crop Science Congress, Brisbane, 26 September-1 October 2004, 29.

[25] Matheka, J.M., Magni, E., Rasha, A.O. and Machuka, J. (2008) In Vitro Selection and Characterization of Drought Tolerant Somaclones of Tropical Maize (Zea mays L.). Biotechnology, 7, 641-650. https://doi.org/10.3923/biotech.2008.641.650

[26] Plomion, C., Costa, P., Dubos, C., Frigerio, J.M., Guehl, J.M. and Queyrens, A. (1999) Genetical, Physiological and Molecular Response of Pinuspinasterto a Progressive Drought Stress. Journal of Plant Physiology, 155, 120-129.

[27] Visser, B. (1994) Technical Aspects of Drought Tolerance. Biotechnology and Development Monitor, 18, 5.

[28] Ehsanpour, A.A. and Razavizadeh, A. (2005) Effect of UV-C on Drought Tolerance of Alfalfa (Medicago sativa) Callus. American Journal of Biochemistry and Biotecnology, 1, 107-110. https://doi.org/10.3844/ajbbsp.2005.107.110

[29] Govindaraj, M., Shanmugasundaram, P., Sumathi, P. and Muthion, A.R. (2010) Simple, Rapid and Cost Effective Screening Method for Drought Resistant Breeding in Pearl Millet. Electronic Journal of Plant Breeding, 1, 590-599.

[30] Berhan, M., Firew, M. and Eyasu, A. (2016) In Vitro Screening of Cactus [Opuntia ficus indicia (L.) Mill] Genotypes for Drought Tolerance. American Journal of Plant Science, 7, 1741-1758. https://doi.org/10.4236/ajps.2016.713163

[31] Rao, S. and Jabeen, F.T.Z. (2013) In Vitro Selection and Characterization of Polyethylene Glycol (PEG) Tolerant Callus Lines and Regeneration of Plantlets from the Selected Callus Lines in Sugarcane (Saccharum officinarum L.). Physiology and Molecular Biology of Plants, 19, 261-268. https://doi.org/10.1007/s12298-013-0162-x

[32] Hassan, N.S., Shaaban, L.D., Hashem, E.A. and Seleem, E.E. (2004) In Vitro Selection for Water Stress Tolerant Callus Line of Helianthus annus L. Cv. Myak. International Journal Agriculture Biology, 6, 13-18.

[33] Shinozaki, K. and Yamaguchi, S.K. (2007) Gene Networks Involved in Drought Stress Response and Tolerance. Journal of Experimental Botany, 58, 221-227. https://doi.org/10.1093/jxb/erl164

[34] Delano, F.J.P., Aviles, A.H., Casarrubias, C.K., Casique, A.G., Castrillon, A.P.A. and Herrera, E.L. (2011) Transcriptomic Analysis of Grain Amaranth (Amaranthus hypochondriacus) Using 454 Pyrosequencing: Comparison with $A$. tuberculatus, Ex- 
pression Profiling in Stems and in Response to Biotic and Abiotic Stress. BioMed Central Genomics, 12, 363. https://doi.org/10.1186/1471-2164-12-363

[35] Grativol, C., Hemerly, A.S. and Ferreira, P.C. (2012) Genetic and Epigenetic Regulation of Stress Responses in Natural Plant Populations. Biochimica et Biophysica Acta, 1819, 176-185. https://doi.org/10.1016/j.bbagrm.2011.08.010

[36] Etienne, H., Montoro, P. and Carron, M.P. (1991) Incidence des paramètres hydriques sur le développement des cals d'Hevea brasiliensis en culture in Vitro. Annales des sciences forestières, INRA/EDP Sciences, 48, 253-265. https://doi.org/10.1051/forest:19910302

[37] Alemanno, L., Ramos, T., Gargadenec, A., Andary, C. and Ferriere, N. (2003) Localization and Identification of Phenolic Compounds in Theobroma cacao L. Somatic Embryogenesis. Annals of Botany, 92, 613-623.

https://doi.org/10.1093/aob/mcg177

[38] Murata, M., Nishimura, M., Murai, N., Haruta, M., Homma, S. and Toh, Y. (2001) A Transgenic Apple Callus Showing Reduced Polyphenol Oxidase Activity and Lower Browning Potential. Bioscience Biotechnologie Biochemistry, 65, 383-388. https://doi.org/10.1271/bbb.65.383

[39] Wu, J. and Lin, L. (2002) Ultrasound-Induced Stress Responses of Panax Ginseng Cells: Enzymatic Browning and Phenolics Production. Biotechnology Progress, 18, 862-866. https://doi.org/10.1021/bp0255210

[40] Gallego Rúa, A.M., Henao Ramírez, A.M., Urrea Trujillo, A.I. and Atehortúa Garcés, L. (2016) Polyphenols Distribution and Reserve Substances Analysis in Cocoa Somatic Embryogenesis. Acta Biológica Colombiana, 21, 335-345. https://doi.org/10.15446/abc.v21n2.50196

[41] Lutts, S., Almansouri, M. and Kinet, J.M. (2004) Salinity and Water Stress Have Contrasting Effects on the Relationship between Growth and Cell Viability during and after Stress Exposure in Durum Wheat. Cellular Plant Sciences, 167, 9-18. https://doi.org/10.1016/j.plantsci.2004.02.014

[42] Tewary, P.K., Sharma, A., Raghunath, M.K. and Sarkar, A. (2000) In Vitro Response of Promising Mulberry (Morus sp) Genotypes for Tolerance to Salt and Osmotic Stresses. Plant Growth Regulation, 30, 17-21. https://doi.org/10.1023/A:1006297830318

[43] Valliyodan, B. and Nguyen, H.T. (2006) Understanding Regulatory Networks and Engineering for Enhanced Drought Tolerance in Plants. Current Opinion Plant Biology, 9, 189-195. https://doi.org/10.1016/j.pbi.2006.01.019

[44] Fulda, S., Mikkat, S., Stegmann, H. and Horn, R. (2011) Physiology and Proteomics of Drought Stress Acclimation in Sunflower (Helianthus annuus L.). Plant Biology, 13, 632-642. https://doi.org/10.1111/j.1438-8677.2010.00426.x

[45] Kaeppler, S.M., Kaeppler, H.F. and Rhee, Y. (2000) Epigenetic Aspects of Somaclonal Variation in Plants. Plant Molecular Biology, 43, 179-188. https://doi.org/10.1023/A:1006423110134

[46] Nag, D.K., Suri, M. and Stenson, E.K. (2004) Both CAG Repeats and Inverted DNA Repeats Stimulate Spontaneous Unequal Sister-Chromatid Exchange in Saccharomyces cerevisiae. Nucleic Acids Research, 32, 5677-5684. https://doi.org/10.1093/nar/gkh901

[47] Arumingtyas, E.L., Widoretno, W. and Indriyani, S. (2012) Somaclonal Variations of Soybeans (Glycine max L. Merr) Stimulated by Drought Stress Based on Random Amplified Polymorphic DNAs (RAPDs). American Journal of Molecular Biology, 2, 
85-91. https://doi.org/10.4236/ajmb.2012.21009

[48] Elmaghrabi, A.M., Rogers, H.J., Francis, D. and Ochatt, S.J. (2017) PEG Induces High Expression of the Cell Cycle Checkpoint Gene WEE1 in Embryogenic Callus of Medicago truncatula: Potential Link between Cell Cycle Checkpoint Regulation and Osmotic Stress. Frontiers in Plant Science, 8, 1479. https://doi.org/10.3389/fpls.2017.01479

[49] Kacem (2017) Sélection in Vitro pour la tolérance au stress hydrique chez le blé dur (Triticum durum Desf): Approche protéomique, transcriptomique et génétique. Thèse de Doctorat, Université des Frères Mentouri Constantine, Algérie, 67. 